\title{
Morphometric Assessment of Corpus Callosum and Cerebral Hemispheres with Magnetic Resonance Imaging
}

\author{
Corpus Callosum ve Hemispherium Cerebri'lerin MRI ile Morfometrik Değerlendirmesi
}

\author{
Necdet KOCABIYIK ${ }^{1}$, Cenk KILIÇ ${ }^{1}$, Barış BAYKAL ${ }^{2}$, Selçuk TUNALI ${ }^{3}$, Bülent YALÇIN ${ }^{1}$, Nail BULAKBAŞI ${ }^{4}$, \\ Hasan OZAN ${ }^{1}$, Mesut AKYOL ${ }^{5}$ \\ ${ }^{1}$ Gülhane Askeri Tip Akademisi, Anatomi Anabilim Dalı, ${ }^{2}$ Trbbi Histoloji-Embriyoloji Anabilim Dah, Ankara \\ ${ }^{3}$ Hacettepe Üniversitesi Tip Fakültesi, Anatomi Anabilim Dal, Ankara \\ ${ }^{4}$ Gülhane Askeri Tip Akademisi, Radyoloji Anabilim Dall, Ankara ${ }^{5}$ Biyoistatistik Bilim Dall, Ankara
}

Submitted / Başvuru tarihi: 29.11.2008 Accepted / Kabul tarihi: 13.04.2009

\begin{abstract}
Objective: In this study, our purpose was to assess the relationship between handedness, footedness and the morphological differences of certain intracranial structures on MR images.
\end{abstract}

Material and Methods: 63 healthy male and 52 healthy female individuals were included in the study. In each subject, 16 measurements of intracranial structures were taken on MR images. Area of corpus callosum, also left and right cerebral hemispheres, length of $\mathrm{CC}$, width of genu (r1), truncus ( $r 2)$, isthmus ( $r 3$ ) and splenium of CC $(\mathrm{r} 4)$ and width of corresponding cerebral hemisphere were measured.

Results: There was a statistically significant difference in R3 (width of the corresponding cerebral hemisphere to $r 3$ ) distance between those using their right feet and those using their left feet. Angle of genu in right-handed people was greater in males than in females. Angle of genu in cases using the left foot was greater in females than in males for standing on one leg.

Conclusion: Morphometric assessment of CC with MR imaging related to handedness and footedness may be useful in demonstrating the relationship between callosal morphology, gender differences and extremity preference in neuroscience.

Key words: Corpus callosum; handedness; footedness; magnetic resonance imaging.
Amaç: Bu çalışmada amacımız, MR görüntülerinde çeşitli intrakranyal yapıların morfolojik farklııkları ile el ve ayak tercih edilirliği arasındaki ilişkiyi değerlendirmekti.

Gereç ve Yöntemler: Çalışma 63 erkek ve 52 kadın sağlıklı bireyi kapsıyordu. Her bir bireyde intrakranyal yapıların 16 ölçümü Manyetik Rezonans görüntülerinde yapıldı. Corpus callosum (CC), sol ve sağ hemispherium cerebri alanları, CC uzunluğu, CC'un genu (r1), truncus $(r 2)$, isthmus ( $r 3$ ) ve splenium ( $r 4)$ kısımlarının genişliği ve bu kısımlara uyan hemispherium cerebri'lerin genişliğini ölçtük.

Bulgular: Sağ ile sol ayağını tercih edenler arasında R3 (r3'e uyan hemispherium cerebri'lerin genişliği) mesafesinde istatistiksel olarak anlamlı farklılık vardı. Sağ elini tercih edenlerde genu açısı erkeklerde kadınlardan daha büyüktü. Tek ayak üzerinde durma için sol ayağını kullanan vakalarda genu açısı kadınlarda erkeklerden daha büyüktü.

Sonuç: El ve ayak tercih edilirliğine ilişkin MR görüntüleriyle CC'un morfometrik değerlendirmesi sinir biliminde CC'un morfolojisi, cinsiyet farklılıkları ve ekstremite tercihi arasındaki ilişkiyi göstermede yararlı olabilir.

Anahtar sözcükler: Corpus callosum; el tercih edilirliği; ayak tercih edilirliği; manyetik rezonans görüntüleme.

Correspondence (iletişim adresi): Dr. Cenk Kılıç. Gülhane Askeri Tıp Akademisi, Anatomi Anabilim Dalı, Ankara, Turkey.

Tel: 03123043508 Fax (Faks): 03123810602 e-mail (e-posta): ckilicmd@yahoo.com

(0) Trakya Üniversitesi Tıp Fakültesi Dergisi. AVES Yayıncılık tarafından basılııştır. Her hakkı sakıldr.

๑ Medical Journal of Trakya University. Published by AVES Publishing. All rights reserved. 


\section{INTRODUCTION}

The corpus callosum (CC), composed of myelinated and unmyelinated axons, links the homotropic regions of the each cerebral hemisphere. Size variations in the CC presumably reflect differences in the size of axons that connect these regions. ${ }^{[1]}$

The size of the CC corresponds to the number of the small and large myelinated fibres connecting the homologous cortical areas of the left and right hemispheres. ${ }^{[2]}$

Investigations of effects of gender differences on the CC and cerebral hemispheres are important. Gender differences in gross corpus callosal neuroanatomy have been observed in several studies. ${ }^{[3-7]}$

In recent studies, no consistent gender difference for callosal size has been observed. Additionally, the morphology of the CC may be influenced by handedness, ${ }^{[8]}$ and cerebral lateralization. ${ }^{[2]}$ The tasks were used in determining handedness (to write a letter legibly, to throw a ball to hit a target, hammering a nail, opening a door, erasing a blackboard, using an eraser on paper, combing the hair and cutting bread etc.) and footedness (kicking, hopping, jumping, first foot used when walking etc.) by some authors. ${ }^{[9]}$

In this study, our purpose was to assess the handedness, footedness and the gender differences of the certain intracranial structures on MR images.

\section{MATERIAL AND METHODS}

This study was conducted on healthy males $(n=63)$ and females $(n=52)$. The age distribution of subjects was $10-84$ years and the mean of age was $37.50 \pm 16.47$. The subjects were divided into 3 groups. Group I consisted of those younger than $25(n=33)$, Group II consisted of those whose age was between 26 and $40(n=43)$, and Group III consisted of those older than $41(n=39)$. The midsagittal and parasagittal MR images of 115 individuals were obtained from the Radiology Department of Faculty of Medicine, Gulhane Military Medical Academy. The age range was 10-84 years. The subjects did not have any neurological or psychiatric disorders and were not taking any drugs or chemical substances affecting the morphology of the brain. Additionally, they had no cerebral tumor or aneurysm. This study was performed between January 2007 and March 2008.

In each case, personal and family medical histories were noted. Subjects with major abnormalities like agenesis of CC were excluded. Also, any change in the handedness at any time, any injury to the limb in the past and incidence of left-handedness in the family or near relatives were recorded for each subject.

Hand and foot preferences were determined through 18 and 9 tasks respectively. The tasks used in determining handedness included opening a door, erasing a blackboard, using an eraser on paper, combing the hair, carrying an object, lifting an object, holding scissors to cut paper, writing on a paper ${ }^{[8]}$ cutting bread, throwing a stone, grasping an object, first hand used when swimming. Those for footedness were kicking, taking the first step forward and/or backward while walking, crossing one thigh over the other while sitting, foot tapping, riding on a two wheeler, standing on one leg, ${ }^{[0]}$ jumping, first foot used when stepping up and/or down, picking pebbles with toes. Furthermore, dominance in the eye and ear were ascertained by two tasks. Anyone preferring left hand for certain tasks (opening a door, erasing a blackboard, cutting bread, combing the hair, carrying an object, lifting an object, jumping, crossing one thigh over the other while sitting, foot tapping and standing on one leg) was assumed to be left-handed.

All sagittal images from lateral right to left through the hemispheres were examined in order to choose the image closest to the midline for each subject. Midsagittal images used in the analyses were those on which the pituitary, three lobules of the cerebellum, spinal cord, pons, and CC could be visualized.

On MR images, 16 measurements of intracranial structures were performed for each individual. Abbreviations used were as follows; r1, maximum dorsoventral width of genu of CC (the distance from the anterior-most point of the genu to the anterior-most point of the inner concavitiy of the anterior part of CC); R1, width of the corresponding cerebral hemisphere to r1; r2, minimum dorsoventral width of trunk of CC; R2, width of the corresponding cerebral hemisphere to r2; r3, minimum dorsoventral width of isthmus of CC; R3, width of the corresponding cerebral hemisphere to $\mathrm{r} 3$; r4, maximum dorsoventral width of splenium of CC; $\mathrm{R} 4$, width of the corresponding cerebral hemisphere to $\mathrm{r} 4$; L, anteroposterior length of CC (the distance from the anterior-most point of the genu to posterior-most point of the splenium) (Figure 1); X, angle of genu of CC (the anterior-most point of the genu was taken as the analysis point). Angle $X$ was between the line originating from the analysis point and touching the dorsal-most point of the $\mathrm{r} 2$ and one tangential to top of the inner convexity of lower surface of the genu of CC); Y, Angle of splenium of CC (the posterior-most point of the splenium was taken as the analysis point. Angle $Y$ was between the line originating from the analysis point and touching the dorsal-most point of the $\mathrm{r} 3$ and one tangential to top of the inner concavity of lower surface of the splenium of CC); IMMA, intracranial measurement of midsagittal area (inferior border of the intracranial area was defined with a line connecting the lip or the foramen magnum and the border of the prepontine cistern immediately posterior to the dens). Then we used the extra-cortical membrane, the optic chiasm and the pituitary stalk as a guide. These measurements are described by previous studies $^{[8,10]}$ (Figure 2); ACC, midsagittal cross sectional area of CC (the CC boundary was circumscribed manu- 


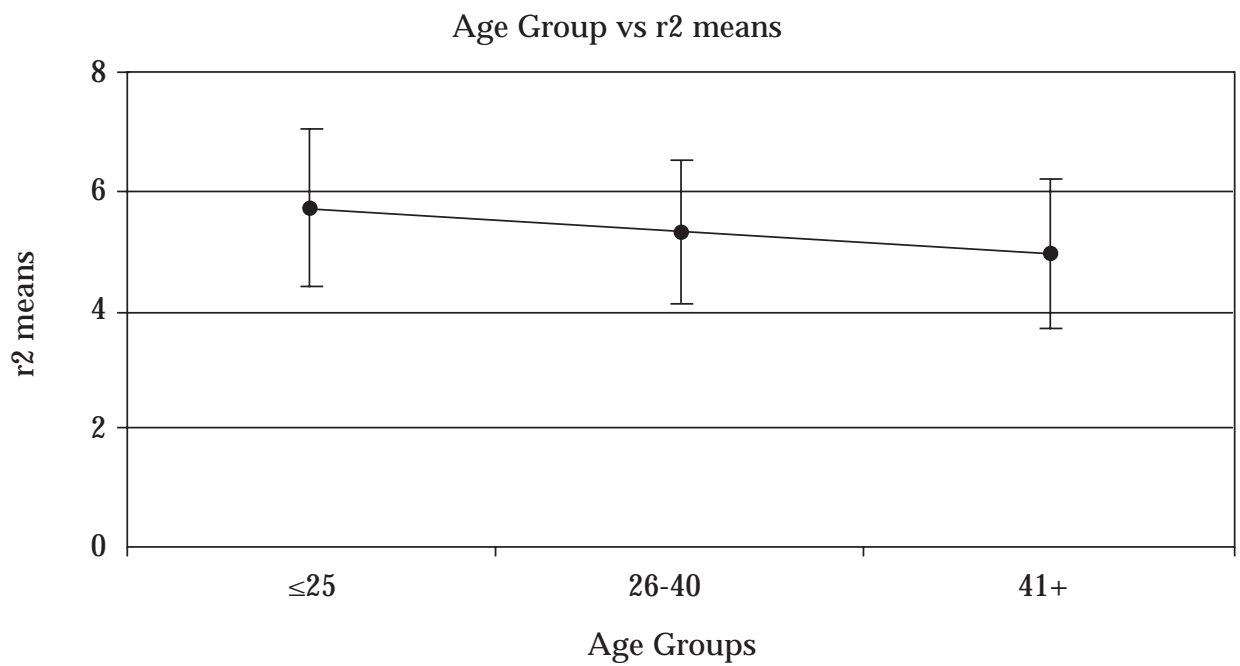

Figure 1. Relationship between age groups and means of r2 (means with SD).

Age Group vs L means

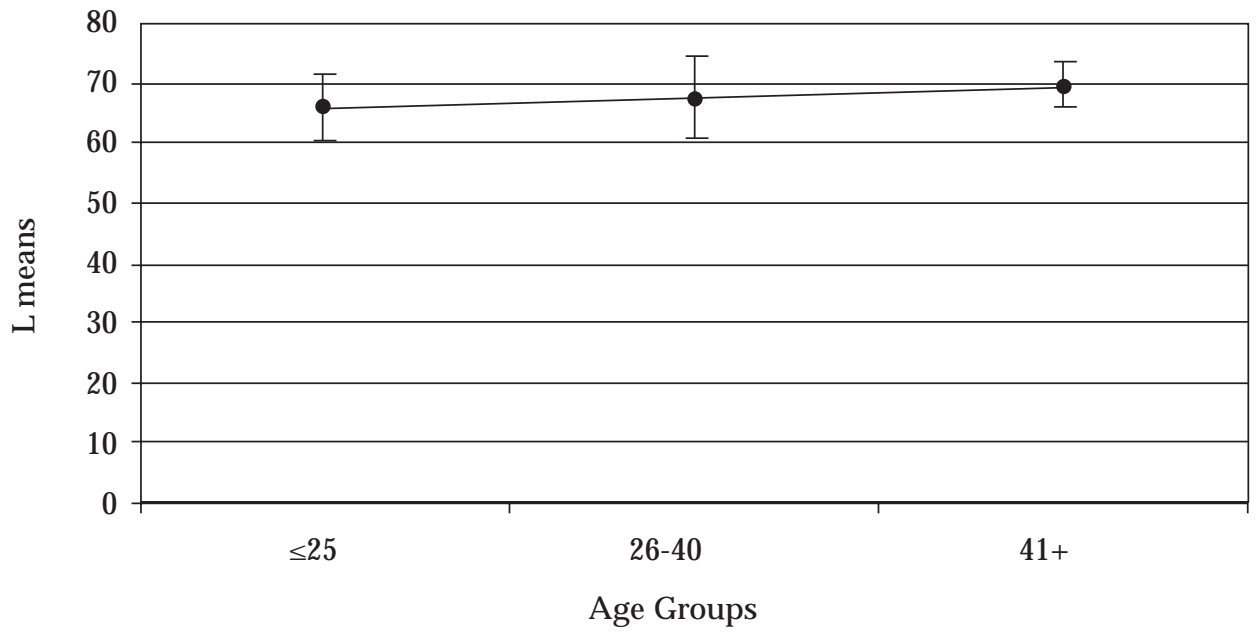

Figure 2. Relationship between age groups and means of L (means with SD).

ally with a trackball device); $\mathrm{AH}$, area of hemisphere (midsagittal supratentorial intracranial area) (Figure 3); $\mathrm{ARH}$, area of right hemisphere of brain (right parasagittal supratentorial intracranial area) and ALH, area of left hemisphere of brain (left parasagittal supratentorial intracranial area).

All patients were examined by 1.5 Tesla superconducting MR scanner (The New Intera Nova, Philips Medical Systems, Best, The Netherlands) using a standard quadrature head coil with version 9 software release. The system was equipped with magnetic field gradients capable of a maximum strength of $33 \mathrm{mT} / \mathrm{m}$ and maximum slew rate of $160 \mathrm{~T} / \mathrm{m} / \mathrm{s}$. Axial and sagittal T1 weighted (583/15 ms, TR/TE, one excitation) spin-echo images were obtained by using $5 \mathrm{~mm}$ slice thickness with a $1 \mathrm{~mm}$ intersection gap, 220x220 mm field of view (FOV) and 256x256 matrix size.

\section{Statistical Analysis}

MS-Excel 2003 and SPSS for Win. Ver. 15.00 (SPSS Inc., Chicago, IL., USA) and NCSS 2007 (Hintze J. (2006), NCSS, PASS, and GESS. NCSS, Kaysville, Utah, USA) software were used for statistical analysis. Distribution of variables was checked graphically and using the Shapiro-Wilk test. Descriptive statistics related to the variables are given as mean \pm standard deviation. Independent Sample $\mathrm{t}$ test (student's $\mathrm{t}$ test) was used for parametric variables and Mann-Whitney U test was used for non-parametric variables. For making comparisons according to age groups, ANOVA test was used for 
parametric variables and Bonferroni post-hoc test was used for defining the source of difference. For nonparametric variables Kruskal-Wallis variance analysis was used and Bonferroni corrected Mann-Whitney U test was used for defining the source of difference. The relationship between age groups and r2 was analyzed using Pearson correlation and the relationship between age groups and L was analyzed using Spearman's (Rho) rank correlation. $\mathrm{p} \leq 0.05$ was set as significant.

\section{RESULTS}

According to age groups, there were no statistically significant differences in r1, R1, R2, r3, R3, r4, R4, AH, ACC, IMMA, X, Y, ARH and ALH ( $p>0.05)$. There was a statistically significant difference between Group I and Group III in $\mathrm{r} 2$ value $(\mathrm{p}=0.035)$. There was a weak negative correlation $(25.6 \%)$ between age and $\mathrm{r} 2$ value, which was statistically significant $\left(\mathrm{R}^{2}=-0.256 ; \mathrm{p}=0.006\right)$ (Fig. 1). Similarly there was a statistically significant difference between Group I and Group III in L value $(Z=2,623$; $\mathrm{p}=0.009)$. There was a weak positive correlation $(27 \%)$ between age and $\mathrm{L}$ value which was statistically significant (Rho=0.270; $\mathrm{p}=0.004$ ) (Fig. 2).

Descriptive statistics of parameters are illustrated in Table 1. Gender comparative results in all parameters showed significant differences between males and females. Certain intracranial structures on MR images are greater in males than in females; which is consistent with our results (Table 1). Reports of other researchers related to ACC are summarized in Table 2. In our study, ACC was $599.7 \pm 105 \mathrm{~mm}^{2}$ in male, $573.6 \pm 129 \mathrm{~mm}^{2}$ in female.

There was a statistically significant difference in R1 $(p=0.004), r 2(p=0.013)$ and angle of genu $(p=0.007)$ distance between the genders (Fig. 3).

There was a statistically significant difference in the midsaggital area between right handed and left handed

Table 2. Values reported by researchers concerned with ACC (midsagittal)

\begin{tabular}{lcc}
\hline ACC $\left(\mathrm{mm}^{2}\right)$ & $\begin{array}{c}\text { Male } \\
\text { Mean } \pm \text { SD }\end{array}$ & $\begin{array}{c}\text { Female } \\
\text { Mean } \pm \text { SD }\end{array}$ \\
\hline .. et al. & $599.7 \pm 105$ & $573.6 \pm 129$ \\
Allen et al. ${ }^{[14]}$ & $661 \pm 9$ & $663 \pm 7$ \\
Kertesz et al. ${ }^{[16]}$ & $724^{*}$ & $716^{*}$ \\
Clarke et al. ${ }^{[5]}$ & $540^{*}$ & $550^{*}$ \\
Pujol et al. ${ }^{[19]}$ & $577 \pm 115$ & $582 \pm 91$ \\
Hardan et al. ${ }^{[15]}$ & & $671 \pm 100^{* *}$ \\
Mostofsky et al. ${ }^{[25]}$ & & $627 \pm 73^{* *}$ \\
Oka et al. ${ }^{[18]}$ & & $657 \pm 80^{* *}$ \\
Laissy et al. ${ }^{[17]}$ & & $636^{* *}$ \\
Suganthy et al. ${ }^{[7]}$ & & $700 \pm 84^{*}$ \\
\hline
\end{tabular}

*Sd Not Presented

${ }^{* *}$ No Gender Specified

Table 1. Descriptive statistics

\begin{tabular}{|c|c|c|c|c|c|c|c|c|}
\hline \multirow[b]{2}{*}{ Parameters } & \multicolumn{3}{|c|}{ Male $(n=63 ; 54.8 \%)$} & \multicolumn{3}{|c|}{ Female $(n=52 ; 45.2 \%)$} & \multirow[b]{2}{*}{ Test Value } & \multirow[b]{2}{*}{$\mathrm{P}$} \\
\hline & Min & $\operatorname{Max}$ & Mean \pm SD & Min & Max & Mean \pm SD & & \\
\hline r1 (mm) & 5.80 & 14.50 & $10.59 \pm 1.73$ & 4.80 & 15.30 & $10.34 \pm 2.18$ & $t=0.695$ & 0.489 \\
\hline $\mathrm{R} 1$ (mm) & 28.80 & 53.70 & $39.57 \pm 5.01$ & 27.20 & 48.00 & $35.95 \pm 4.82$ & $Z=3.864$ & $<0.001^{*}$ \\
\hline $\mathrm{r} 2(\mathrm{~mm})$ & 2.90 & 9.30 & $5.54 \pm 1.19$ & 2.10 & 9.20 & $5.01 \pm 1.29$ & $\mathrm{t}=2.289$ & $0.024^{*}$ \\
\hline $\mathrm{R} 2(\mathrm{~mm})$ & 33.30 & 51.20 & $42.26 \pm 3.79$ & 31.80 & 50.00 & $40.73 \pm 3.51$ & $\mathrm{t}=2.231$ & $0.028^{*}$ \\
\hline r3 (mm) & 1.20 & 6.30 & $3.90 \pm 1.23$ & 1.00 & 6.80 & $3.72 \pm 1.09$ & $\mathrm{t}=0.848$ & 0.398 \\
\hline $\mathrm{R} 3(\mathrm{~mm})$ & 36.80 & 63.60 & $50.32 \pm 4.85$ & 39.50 & 56.00 & $48.79 \pm 3.88$ & $\mathrm{t}=1.840$ & 0.068 \\
\hline $\mathrm{r} 4(\mathrm{~mm})$ & 5.40 & 14.30 & $10.59 \pm 1.82$ & 4.70 & 15.00 & $10.32 \pm 2.15$ & $\mathrm{t}=0.753$ & 0.453 \\
\hline $\mathrm{R} 4$ (mm) & 33.90 & 76.30 & $51.34 \pm 8.95$ & 36.60 & 74.20 & $48.45 \pm 7.81$ & $Z=1.899$ & 0.058 \\
\hline $\mathrm{L}(\mathrm{mm})$ & 56.60 & 81.60 & $67.73 \pm 4.69$ & 38.50 & 84.00 & $67.49 \pm 6.73$ & $Z=0.115$ & 0.908 \\
\hline$X^{o}$ & 29.70 & 116.10 & $74.06 \pm 19.99$ & 34.50 & 112.80 & $69.61 \pm 16.37$ & $\mathrm{t}=1.290$ & 0.200 \\
\hline IMMA $\left(\mathrm{mm}^{2}\right)$ & 9418.60 & 15973.90 & $13896.93 \pm 1061.64$ & 10533.60 & 15086.60 & $13106.20 \pm 814.64$ & $Z=4.394$ & $<0.001^{*}$ \\
\hline $\mathrm{ACC}\left(\mathrm{mm}^{2}\right)$ & 40.80 & 853.70 & $599.74 \pm 105.23$ & 53.50 & 852.60 & $573.61 \pm 129.91$ & $Z=0.753$ & 0.451 \\
\hline $\mathrm{AH}\left(\mathrm{mm}^{2}\right)$ & 5419.20 & 10280.90 & $8895.89 \pm 805.47$ & 6224.40 & 10198.20 & $8284.75 \pm 698.24$ & $Z=4.355$ & $<0.001^{*}$ \\
\hline $\mathrm{ARH}\left(\mathrm{mm}^{2}\right)$ & 6132.00 & 10666.80 & $8975.84 \pm 789.36$ & 6304.30 & 9983.90 & $8402.55 \pm 725.30$ & $\mathrm{t}=4.020$ & $<0.001^{*}$ \\
\hline ALH $\left(\mathrm{mm}^{2}\right)$ & 6065.40 & 10643.40 & $8815.69 \pm 810.69$ & 6803.20 & 9896.80 & $8225.13 \pm 636.28$ & $\mathrm{t}=4.276$ & $<0.001^{*}$ \\
\hline
\end{tabular}

*: Statistical significant

Table 1. r1 width of genu of CC, R1 width of the corresponding cerebral hemisphere to r1, r2 width of trunk of CC, R2 width of the corresponding cerebral hemisphere to $\mathrm{r} 2, \mathrm{r} 3$ width of isthmus of CC, R3 width of the corresponding cerebral hemisphere to r3, r4 width of splenium of CC, R4 width of the corresponding cerebral hemisphere to $\mathrm{r} 4, \mathrm{~L}$ anteroposterior length of $\mathrm{CC}, \mathrm{X}$ angle of genu of CC, Y angle of splenium of CC, ACC midsagittal cross sectional area of CC, ARH area of right hemisphere of brain, ALH area of left hemisphere of brain, IMMA intracranial measurement of midsagittal area of the brain. 
subjects $(p=0.048)$. Also, there was a statistically significant difference in $\mathrm{r} 3$ distance between those using their right hand and those using their left hand in cleaning the blackboard ( $\mathrm{p}=0.041)$ (Fig. 4).

There was a statistically significant difference in R3 distance between those using their right feet and those using their left feet $(p=0.009)$. Also, there was a statistically significant difference in R1 distance between those using their right feet and those using their left feet in jumping $(p=0.047)$. Differences in other parameters related to gender and tasks are shown in Table 3.

Angle of genu in right-handed people was greater in males than in females (male, 79.34 \pm 19.14 ; female, $64.38 \pm 15.97$ ). Angle of genu in cases using the left foot was greater in females than in males (male, 61.15 \pm 19.45 ; female, $76.97 \pm 12.11$ ) for standing on one leg. In addition, angle of genu in cases using the left foot while using the right hand was greater in females than in males in our study (Fig. 5).

\section{DISCUSSION}

The CC is the largest fiber pathway of the brain in human and links the cerebral cortex of each hemisphere. The most conspicuous feature is the great commissure, the CC, a broad arched band in the floor of the central region of the longitudinal fissure. Its curved anterior part is the genu, continuous below with the rostrum and narrowing rapidly as it passes back to the upper end of the lamina terminalis. The genu continues above into the trunk, the main part of the commissure, which arches up and back to a thick, rounded posterior extremity, the splenium. ${ }^{[1]}$

The findings regarding the morphometry of CC are important in the diagnosis of neurological diseases. It has been discussed that these measurements might be related to some diseases. ${ }^{[12]}$

There are many studies where CC and cerebral hemisphere widths and areas have been measured on MR images. ${ }^{[13-19]}$

A longer CC in males has been reported in two studies. ${ }^{[7,20]}$ However, most researchers have not identified sexual dimorphism in callosal length..$^{[14,21]}$

Several studies reported that the measurements of the anterior parts of the corpus callosum (rostrum, genu and anterior parts of the trunk) were decreased during normal aging. ${ }^{\left[{ }^{7,22-25]}\right.}$ Takeda et al. reported that the widths of rostrum, body and splenium of the corpus callosum became thinner with age. ${ }^{[25]}$ Suganthy et al. ${ }^{[7]}$ reported that the length of the corpus callosum increased with age and regression equations for predicting age was derived from the length of the corpus callosum. In addition, they measured the average callosal length as $71.6 \pm 4.7 \mathrm{~mm}$. We found the average anteroposterior length of CC as

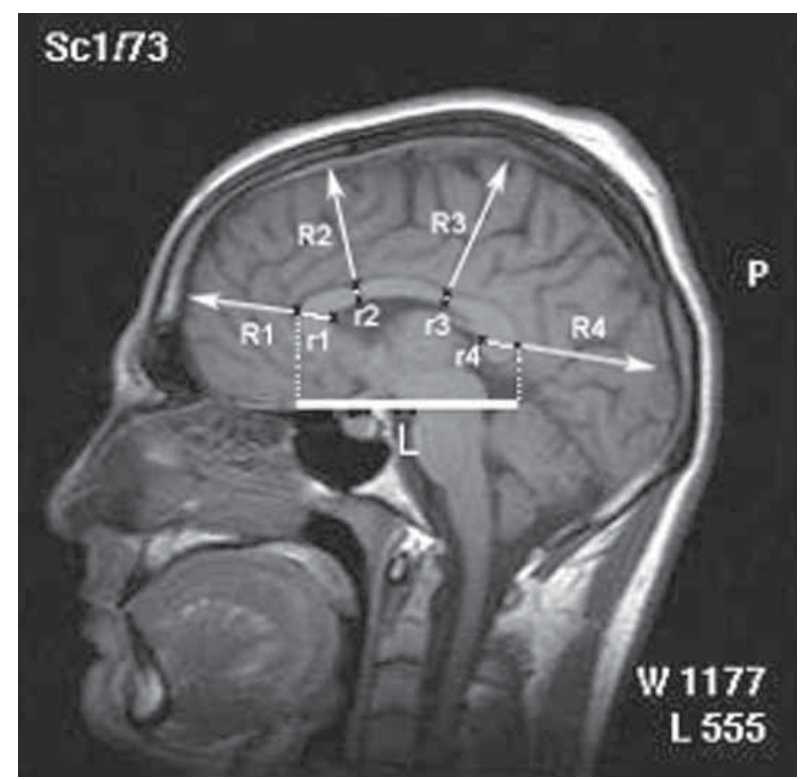

Figure 3. Mid-sagittal cross sectional image. Width of genu (r1); width of trunk (r2); width of isthmus (r3); width of splenium ( $r 3)$, width of cerebral hemisphere of corresponding to $r 1, r 2, r 3, r 4(R 1, R 2, R 3, R 4)$, length of $C C(L)$.

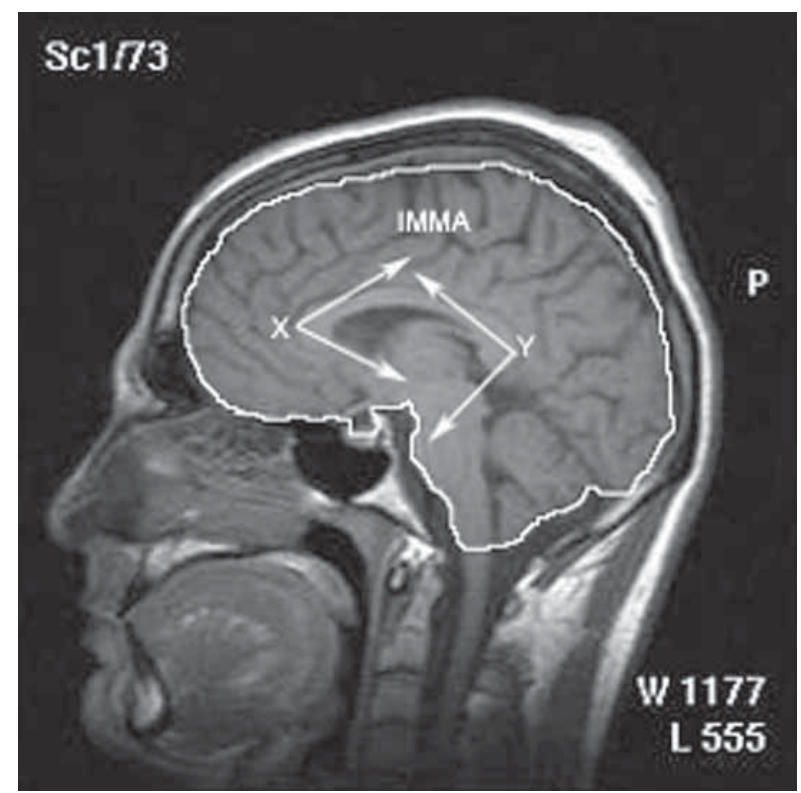

Figure 4. Mid-sagittal intracranial area of brain. Angle of genu $(X) ;$ angle of splenium (Y); intracranial measurement of midsagittal area of brain (IMMA).

$67.72 \pm 4.69 \mathrm{~mm}$ in male, $67.48 \pm 6.73 \mathrm{~mm}$ in female. We did not identify any differences in the length of CC between genders (Table 1).

Schmitt et al. ${ }^{[20]}$ found the area of CC as $782 \pm 73 \mathrm{~mm}^{2}$ and Peterson et al. ${ }^{[26]}$ as $785 \pm 154 \mathrm{~mm}^{2}$. These results were greater than that of other studies. Our results correspond to the results of other researchers in Table 2. 
Denenberg et al. ${ }^{[27]}$ have evaluated the total area of CC. Regional widths were found to be sensitive to gender by handedness interactions in the anterior body, with right-handed females and left-handed males being larger. In the posterior body, males had wider callosa than females. A further analysis within the 'isthmus' region compared consistent and non-consistent righthanded males and females. Consistent right-handed males and both female groups had smaller callosa than non-consistent right-handed males. ${ }^{[27]}$

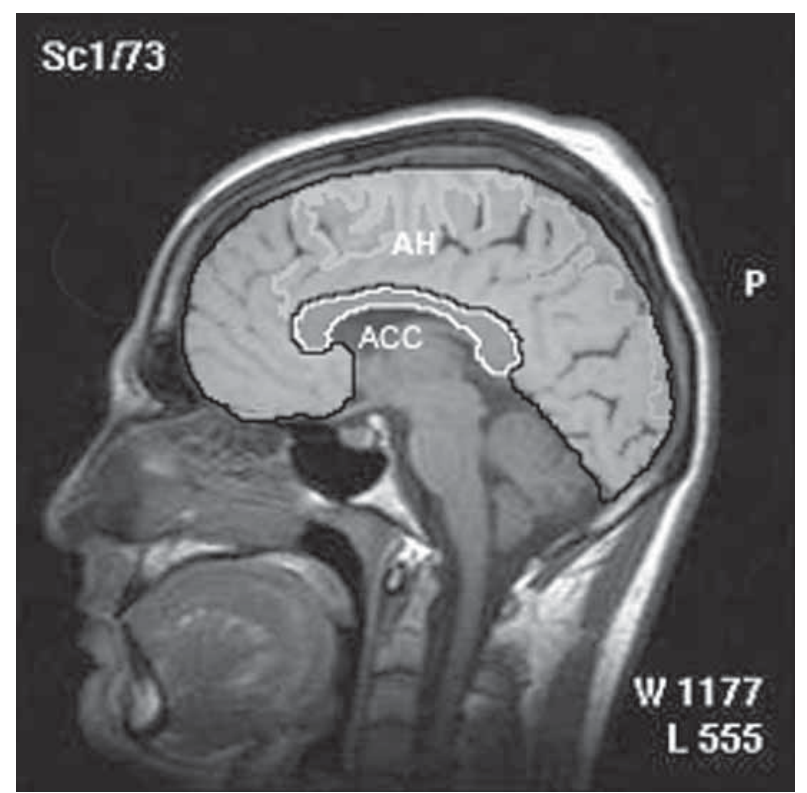

Figure 5. Mid-sagittal cross sectional area of corpus callosum. Midsagittal cross sectional area of CC (ACC); area of hemisphere $(A H)$.
Mostofsky et al. ${ }^{[28]}$ have found the intracranial midsagittal area as $15900 \pm 1166 \mathrm{~mm}^{2} \cdot{ }^{[13]}$ Allen reported that values of the area of hemispherium (midsagittal area) were $9364 \pm 73 \mathrm{~mm}^{2}$ in male, $8993 \pm 65 \mathrm{~mm}^{2}$ in female. In our study, IMMA was $13896.93 \pm 1061.64 \mathrm{~mm}^{2}$ in male, $13106.2 \pm 814.63 \mathrm{~mm}^{2}$ in female and $\mathrm{AH}$ was $8895.89 \pm 805.47 \mathrm{~mm}^{2}$ in male, $8284.74 \pm 698.24 \mathrm{~mm}^{2}$ in female. The former results were consistent with ours.

Cowell et al. ${ }^{[29]}$ have assessed the area, axis length and widths of CC. They reported that emales did not attain maximum width until age 41-50 whereas males had peaked at 20 years and declined thereafter.

Although gender differences have been reported in the genu $^{[6]}$, trunk ${ }^{[30]}$, splenium and the area of the CC in the literature ${ }^{[12,21]}$, in our study R1 and r2 were significantly different between the genders, being greater in the male (Table 1). Suganthy et al. ${ }^{[7]}$ have reported the width of splenium as $10.7 \pm 1.9 \mathrm{~mm}$; in our study, r4 was $10.59 \pm 1.82 \mathrm{~mm}$ in males and $10.32 \pm 2.15 \mathrm{~mm}$ in females.

Oka et al. ${ }^{[17]}$ have reported gender differences in four specific angles of the CC. We found the angle of genu as $74.06 \pm 19.98^{\circ}$ in male, and $69.61 \pm 16.36^{\circ}$ in female. The average angle of genu in right-handed subjects was greater in males than in females. The average angle of genu among subjects using left foot for standing on one leg was greater in females than in males.

Dunham and Hopkins ${ }^{[31]}$ suggest that right-handed chimpanzees have a larger CC than left-handed chimpanzees. We did not find handedness differences for midsagittal cross sectional area of CC values in humans.

Table 3. Statistically significant differences in some parameters related to gender and tasks

\begin{tabular}{|c|c|c|c|c|c|c|c|c|}
\hline Parameters & Groups & $\mathrm{R} 1$ & $\mathrm{r} 2$ & $\mathrm{R} 2$ & r3 & R3 & $\mathrm{R} 4$ & $X$ \\
\hline Gender & $\begin{array}{c}\text { Male } \\
\text { Female }\end{array}$ & $\Delta$ & $\Delta$ & 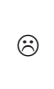 & (2) & 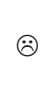 & 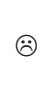 & $\nabla$ \\
\hline Opening the door & $\begin{array}{c}\text { Left } \\
\text { Right }\end{array}$ & $:$ & 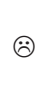 & $:$ & 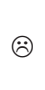 & (2) & (2) & : \\
\hline Erasing a blackboard & $\begin{array}{l}\text { Left } \\
\text { Right }\end{array}$ & $\ddot{\theta}$ & 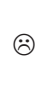 & 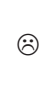 & $\frac{\Delta}{\nabla}$ & 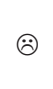 & 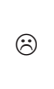 & : \\
\hline Jumping & $\begin{array}{c}\text { Left } \\
\text { Right }\end{array}$ & $\Delta$ & 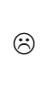 & 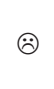 & 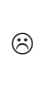 & 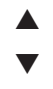 & : & : \\
\hline Cutting bread & $\begin{array}{c}\text { Left } \\
\text { Right }\end{array}$ & 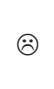 & 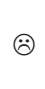 & $\frac{\Delta}{\nabla}$ & 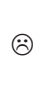 & 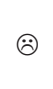 & $:$ & 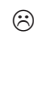 \\
\hline Combing the hair & $\begin{array}{l}\text { Left } \\
\text { Right }\end{array}$ & (2) & (2) & 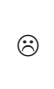 & (2) & 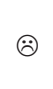 & (2) & (2) \\
\hline Carrying an object & $\begin{array}{l}\text { Left } \\
\text { Right }\end{array}$ & 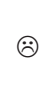 & : & 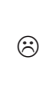 & (2) & 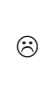 & $\frac{\Delta}{\nabla}$ & (2) \\
\hline Lifting an object & $\begin{array}{c}\text { Left } \\
\text { Right }\end{array}$ & 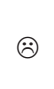 & 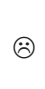 & 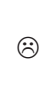 & 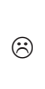 & :) & $\Delta$ & : \\
\hline
\end{tabular}


Witelson ${ }^{[8]}$ reported that the isthmus area was greater in left handed than right-handed subjects, whereas we did not find handedness differences for the width of isthmus of CC (r3) values.

Studies that have been performed to analyse the relationship between extremity preference and the structural differences of corpus callosum are cross-sectional. We suggest that the results of our cross-sectional study show that extremity preference may be a cause or a result of the structural differences of corpus callosum. Additionally, we consider that long term and ethically suitable cohort studies and visualisation techniques should be used to determine whether the structural differences of corpus callosum are a result or the cause of observed clinical signs.

\section{Acknowledgments}

We thank Radiology Technician Huseyin Koroglu for contribution and assisting in the care of the subjects during scanning.

\section{Conflict of Interest}

No conflict of interest declared by the authors.

\section{REFERENCES}

1. Baumgardner TL, Singer HS, Denckla MB, Rubin MA, Abrams MT, Colli MJ, et al. Corpus callosum morphology in children with Tourette syndrome and attention deficit hyperactivity disorder. Neurology 1996;47:477-82.

2. Stancak AJ, Carl HL, Rumyana KF. Lateralization of movement-related potentials and the size of corpus callosum. Neuroreport 2000;11:329-32.

3. Bell AD, Variend S. Failure to demonsrate sexual dimorphism of the corpus callosum in childhood. Journal of Anatomy 1985;143:143-7.

4. Bishop KM, Wahlsten D. Sex differences in the human corpus callosum: Myth or reality? Neuroscience 1997;21:581-601.

5. Clarke S, Kraftsik R, Van der Loos H, Innocenti G M. Forms and easures of adult and developing human corpus callosum: is there sexual dimorphism? The Journal of Comparative Neurology 1989;280:213-30.

6. Hoff AL, Nea C, Kushner M, DeLisi LE. Gender differences in corpus callosum size in first-episode schizophrenics. Biological Psychiatry 1994;35:913-9.

7. Suganthy J, Raghuram L, Antonisamy B, Vettivel S, Madhavi C, Koshi R. Gender- and age-related differences in the morphology of the corpus callosum. Clinical Anatomy 2003;16:396-403.

8. Witelson SF Hand and sex differences in the isthmus and genu of the human corpus callosum. Brain 1989; 112: 799-835.

9. Hebbal GV, Mysorekar VR. Anatomical and behavioural asymmetries in right and left handers from India. Annals of Anatomy 2003;185:267-75.

10. Koshi R, Koshi T, Jeyaseelan L, Vettivel, S. Morphology of the corpus callosum in human fetuses. Clinical Anatomy 1997;10:22-6.

11. Williams PL, Bannister LH, Berry MM, Standring SM, (editors). Gray's Anatomy. Edinburgh: Churchill Livingstone; 1995.

12. Mazziotta JC, Toga AW, Evans AC, Fox B, Lancester J. Probabilistic atlas of human brain. Theory rationale for its development. Neuroimage 1995;2:89-101.
13. Allen LS, Riche MF, Chai YM, Gorski RAJ . Sex differenced in the corpus callosum of the living human being. Neuroscience 1991;11:933-42.

14. Hardan AY, Minshew NJ, Keshavan MS. Corpus callosum size in autism. Neurology 2000; 55:1033-6.

15. Kertesz A, Polk M, Howell J, Black SE. Cerebral dominance, sex, and callosal size in MRI. Neurology 1987;37:1385-8.

16. Laissy JP, Patrux B, Duchateau C, Hannequin D, Hugonet $\mathrm{P}$, Ait-Yahia $\mathrm{H}$ et al. Midsagittal MR measurements of the corpus callosum in healthy subjects and diseased patients: a prospective survey. AJNR American Journal of Neuroradiology 1993;14:145-54.

17. Oka S, Miyamoto O, Janjua NA, Honjo-Fujiwara N, Ohkawa M, Nagao S, et al. Re-evaluation of sexual dimorphism in human corpus callosum. Neuroreport 1999;10:937-40.

18. Pujol J, Vendrell P, Junque C, Marti-Vilalta JL, Capdevila A. When does human brain development end? Evidence of corpus callosum growth up to adulthood. Annals of Neurology 1993;34:71-5.

19. Schmitt JE, Eliez S, Warsofsky IS, Bellugi U,Reiss AL. Corpus callosum morphology of Williams syndrome: relation to genetics and behavior. Developmental Medicine Child Neurology 2001;43:155-9.

20. Hopper KD, Patel S, Cann TS, WilcoxT, Schaeffer JM. The relationship of age, gender, handedness, and sidedness to the size of the corpus callosum. Academic Radiology 1994;1:243-8.

21. DeLacoste-Utamsing C, Holloway RL. Sexual dimorphism in the human corpus callosum. Science 1982;216:1431-2.

22. Pozzilli C, Bastianello S, Bozzao A, Pierallini A, Giubilei F, Argentino C, Bozzao L. No differences in corpus callosum size by sex and aging. A quantitative study using magnetic resonance imaging J Neuroimaging 1994;4:218-21.

23. Weis S, Kimbacher M, Wenger E, Neuhold A. Morphometric analysis of the corpus callosum using MR: correlation of measurements with aging in healthy individuals. AJNR Am J Neuroradiol 1993;14:637-45.

24. Parashos IA, Wilkinson WE, Coffey CE. Magnetic resonance imaging of the corpus callosum: predictors of size in normal adults. J Neuropsychiatry Clin Neurosci. 1995;7:35-41.

25. Takeda S, Hirashima Y, Ikeda H, Yamamoto H, Sugino M, Endo S. Determination of indices of the corpus callosum associated with normal aging in Japanese individuals. Neuroradiology 2003;45:513-8.

26. Peterson BS, Leckman JF, Duncan CS, Wetzles R, Riddle MA, Hardin MT, et al. Corpus callosum morphology from magnetic resonance images in Tourette's syndrome. Psychiatry Research 1994;55:85-99.

27. Denenberg VH, Kertesz A, Cowell PE. A factor analysis of the human's corpus callosum. Brain Research 1991;548:126-32.

28. Mostofsky SH, Wendlandt JBS, Cutting L, Denckla MB, Singer HS. Corpus callosum measurements in girls with Tourette syndrome. Neurology 1999;53:1345-7.

29. Cowell PE, Allen LS, Zalatimo NS, Denenberg VH. A developmental study of sex and age interactions in the human corpus callosum. Brain Research Developmental Brain Research 1992;66:187-92.

30. Clarke JM, Zaidel E. Anatomical-behavioral relationships corpus callosum morphometry and hemispheric specialization. Behavioural Brain Research 1994;64:185-202.

31. Dunham LA, Hopkins WD. Sex and Handedness Effects on Corpus Callosum Morphology in Chimpanzees (Pan troglodytes) Behavioral Neuroscience 2006;120:1025-32. 